\title{
Diaphragmatic herniation due to massive hepatomegaly in a patient with pulmonary arterial hypertension
}

\author{
Irina Timofte, ${ }^{1}$ Darryn Potosky, ${ }^{2}$ Gautam V Ramani, ${ }^{3}$ Robert M Reed ${ }^{4}$
}

${ }^{1}$ Division of Pulmonary and Critical Care Medicine, University of Maryland, Baltimore, Maryland, USA ${ }^{2}$ Division of Gastroenterology and Hepatology, Department of Medicine, University of Maryland, Baltimore,

Maryland, USA ${ }^{3}$ Department of Cardiology, University of Maryland, Baltimore, Maryland, USA ${ }^{4}$ Department of Pulmonary and Critical Care Medicine, University of Maryland, Baltimore, Maryland, USA

Correspondence to Dr Robert Michael Reed rreed@medicine.umaryland.edu

Accepted 21 May 2015
CrossMark

\begin{tabular}{l}
\hline To cite: Timofte I, \\
Potosky D, Ramani GV, \\
et al. BMJ Case Rep \\
Published online: [please \\
include Day Month Year] \\
doi:10.1136/bcr-2014- \\
208449 \\
\hline
\end{tabular}

\section{DESCRIPTION}

A 56-year-old woman with severe pulmonary arterial hypertension $(\mathrm{PAH})$ presented with right upper quadrant abdominal pain. The patient was diagnosed with PAH 5 years prior and started on oral therapy, but due to worsening pulmonary haemodynamics and symptoms, intravenous treprostinil was initiated. Imaging studies demonstrated hepatomegaly and a liver biopsy showed hepatic venous outflow obstruction and findings consistent with nodular regenerative hyperplasia. There was no evidence of hepatic fibrosis. Despite treatment with intravenous treprostinil, the patient had persistent dyspnoea and ongoing symptoms of right heart failure with worsening right upper quadrant abdominal pain. CT scan of the chest, abdomen and pelvis showed marked hepatomegaly with herniation of the caudate lobe into the right hemithorax (figure 1). Liver herniation and cardiomegaly resulted in restrictive pulmonary function with a total lung capacity of $64 \%$.

Survival for patients with PAH is closely associated with right ventricular function. ${ }^{1}$ Right heart failure is a late consequence of $\mathrm{PAH}$ hypertension that can lead to oedema, ascites and congestive hepatopathy. The underlying pathophysiology involved in hepatic dysfunction from right heart failure involves passive congestion secondary to increased right atrial pressures and/or low cardiac output with decreased arterial perfusion. These deleterious haemodynamics are further amplified by concomitant hypoxia. ${ }^{2}$ Radiological evidence of hepatomegaly or elevated liver enzymes, particularly bilirubin, is a marker of poor prognosis ${ }^{3}$ and should prompt referral for advanced treatment options, including lung transplantation.

\section{Learning points}

- Development of right heart failure and congestive hepatopathy are signs of poor prognosis in patients with pulmonary arterial hypertension and should prompt therapeutic modifications and consideration for lung transplantation.

- In the absence of significant fibrosis in the liver, hepatic dysfunction and hepatomegaly can completely reverse with correction of the right heart failure.

Competing interests None declared.

Patient consent Obtained.

Provenance and peer review Not commissioned; externally peer reviewed.

\section{REFERENCES}

1 Vonk-Noordegraaf A, Haddad F, Chin KM, et al. Right heart adaptation to pulmonary arterial hypertension: physiology and pathobiology. J Am Coll Cardiol 2013;62(25 Suppl):D22-33.

2 Møller S, Bernardi M. Interactions of the heart and the liver. Eur Heart J 2013;34:2804-11.

3 Shinagawa $H$, Inomata $T$, Koitabashi $T$, et al. Increased serum bilirubin levels coincident with heart failure decompensation indicate the need for intravenous inotropic agents. Int Heart J 2007;48:195-204. 
Copyright 2015 BMJ Publishing Group. All rights reserved. For permission to reuse any of this content visit http://group.bmj.com/group/rights-licensing/permissions.

BMJ Case Report Fellows may re-use this article for personal use and teaching without any further permission.

Become a Fellow of BMJ Case Reports today and you can:

- Submit as many cases as you like

- Enjoy fast sympathetic peer review and rapid publication of accepted articles

- Access all the published articles

- Re-use any of the published material for personal use and teaching without further permission

For information on Institutional Fellowships contact consortiasales@bmjgroup.com

Visit casereports.bmj.com for more articles like this and to become a Fellow 